\title{
PENGUKURAN KUALITAS SISTEM KRS ONLINE MENGGUNAKAN METODE WEBQUAL
}

\author{
Dafid \\ STMIK GI MDP \\ Jl. Rajawali No.14 Palembang \\ E-mail : dafid@mdp.ac.id
}

\begin{abstract}
ABSTRAK
Berbagai inovasi dilakukan oleh suatu perguruan tinggi untuk meningkatkan layanan akademik terhadap mahasiswanya. Pemanfaatan sistem informasi menjadi hal yang lumrah dilakukan. STMIK XYZ telah menerapkan suatu sistem informasi dalam hal pengisian KRS online dengan nama Prisma online. Keberadaan sistem yang digunakan harus dapat dipastikan kualitas layanannya supaya layanan yang diberikan selalu berada dalam kondisi yang optimal. Untuk mengukur kualitas Prisma online tersebut pada penelitian ini digunakan metode WebQual 4.0 yang diukur berdasarkan persepsi dari mahasiswa terhadap beberapa indikator yang telah ditentukan. Pengumpulan data dilakukan dengan melakukan kuesioner terhadap mahasiswa STMIK XYZ Palembang yang diisi dengan menggunakan Google Form. Pengujian variabel yang berkaitan dengan dimensi kualitas dilakukan dengan menggunakan analisis regresi linier berganda. Hasil penelitian ini menunjukan bahwa terdapat korelasi positif yang cukup berarti untuk variabel Usability $(U)$ dan Information(I) terhadap variabel Satisfaction $(S)$ dengan nilai $0,5<\mathrm{kk} \leq 0,8$, sedangkan untuk variabel A dan $\mathrm{S}$ menunjukkan adanya korelasi positif yang tinggi atau kuat dengan nilai $0,6<\mathrm{kk} \leq 0,8$.
\end{abstract}

Kata kunci : kualitas, webqual, sistem informasi

\section{ABSTRACT}

Various innovations are carried out by a university to improve academic services for its students. Utilization of information systems is common. STMIK XYZ has implemented an information system in terms of filling KRS online with the name Prisma online. The existence of the system used must be ensured the quality of services so that the services provided are always in optimal conditions. To measure the quality of Prisma online in this study used the WebQual 4.0 method, which is measured based on the perception of students of some predetermined indicators. Data collection was carried out by conducting a questionnaire on the students of STMIK XYZ Palembang filled using Google Forms. Testing variables related to the quality dimension is done by using multiple linear regression analysis. The results of this study indicate that there is a significant positive correlation for the variable Usability $(U)$ and Information (I) to the Satisfaction (S) variable with a value of $0.5<k k \leq 0.8$, while for variables $A$ and $S$ show a positive correlation high or strong with a value of $0.6<k k \leq 0.8$.

Keywords: quality, webqual, information system

\section{PENDAHULUAN}

Dari seluruh perguruan tinggi yang ada tentu kesemuanya menginginkan kelancaran dalam pelaksanaan kegiatan akademiknya. Berbagai cara dilakukan, mulai dari penyediaan fasilitas kampus secara baik dan lengkap sampai dengan pemanfaatan teknologi informasi. STMIK XYZ sesuai dengan mottonya sebagai Kampus Inovasi telah mengimplentasikan Sistem Informasi di semua bentuk kegiatan akademiknya. Salah satu kegiatan tersebut adalah pengisian Kartu Rencana Studi (KRS) yang rutin dilakukan oleh mahasiswa setiap awal semester baru. Saat ini pengisian KRS di STMIK XYZ telah dilakukan secara online (berbasis web) dengan nama sistem informasi Prisma Online. Sistem Informasi ini mempermudah mahasiswa karena pengisian dapat dilakukan dimana saja dan kapan saja sehingga mahasiswa tidak perlu harus ke kampus lagi seperti yang sebelumnya hanya untuk melakukan pengisian KRS. Keberadaan sistem yang digunakan tentu saja harus dapat dipastikan terhadap kualitas layanan yang diberikan supaya pengguna sistem tidak kecewa. Untuk memastikan apakah 
layanan dari sistem informasi yang diberikan selama ini telah memenuhi keinginan mahasiwa maka perlu adanya suatu pengukuran terhadap kualitas sistem informasi yang digunakan. Dengan adanya pengukuran tersebut akan diketahui seberapa besar tingkat kualitasnya sehingga pihak kampus dapat mengambil langkah-langkah yang diperlukan untuk memperbaiki kualitas layanan yang masih kurang, mempertahankan kualitas layanan yang sudah baik dan berusaha untuk meningkatkan kualitas layanan yang ada. Berdasarkan kajian terhadap penelitian sebelumnya, penelitian terhadap Sistem KRS online STMIK XYZ dengan menggunakan metode khusus pengukuran web belum pernah dilakukan. Penelitian yang pernah dilakukan sebelumnya[1] menggunakan USE Questionnaire. Penelitian tersebut menitikberatkan pengukuran pada aspek usablitiy yang merupakan tingkat dimana sebuah produk bisa digunakan oleh pengguna tertentu untuk mencapai tujuan tertentu dengan efektif, efisien dan memperoleh kepuasan dalam konteks penggunaannya[2]. Penelitian tersebut melihat hubungan antara variabel bebas yaitu variabel

usefulness, ease of use, dan ease of learning terhadap variabel terikat yaitu satisfaction secara simultan maupun parsial. Hasil penelitian menunjukkan nilai persentase kelayakan sebesar $85,89 \%$ artinya hasil pengukuran usability aplikasi KRS secara online memiliki nilai sangat layak dengan faktor dominan yang mempengaruhi kepuasan user dalam menggunakan aplikasi pengisian KRS online adalah ease of use (kemudahan penggunaan) dengan nilai rata-rata 46,4. Penelitian ini melengkapi penelitian sebelumnya dengan menggunakan metode WebQual yang khusus mengukur kualitas dari suatu web, dengan demikian hasil yang diperoleh bisa lebih akurat. Hasil penelitian ini diharapkan dapat membantu manajemen dan pihak terkait untuk mengambil langkahlangkah yang diperlukan dalam rangka memperbaiki dan meningkatkan kualitas Prisma Online.

\subsection{Metode WebQual}

WebQual merupakan salah satu metode atau teknik pengukuran kualitas website berdasarkan persepsi pengguna akhir. Metode ini merupakan pengembangan dari SERVQUAL yang banyak digunakan sebelumnya pada pengukuran kualitas jasa. WebQual sudah mulai dikembangkan sejak tahun 1998 dan telah mengalami beberapa interaksi dalam penyusunan dimensi dan butir pertanyaannya. Sampai saai ini pengembangan WebQual sudah mencapai versi WebQual 4.0 yang disusun berdasarkan penelitian pada tiga area (dimensi) kualitas sebagaimana termuat dalam tabel 1 sampai tabel 3.[3] Webqual ini berbasis pada Quality Function Deployment (QFD). Pada pengembangan Webqual 1.0, penguatan yang dilakukan hanya pada information quality dengan dimensi ease of use, experience, information, communication dan integration. Sedangkan pada versi WebQual 2.0 ada peningkatan pada perspektif interaction lalu pada versi WebQual 3.0 dimensinya menjadi web information quality (accurate, timely, reliable), web interaction quality (good reputation, safe to transact, personal data secure,will deliver as promise) site design quality (easy tonavigate, attractive appearance, project a sense of competency).

\subsection{Dimensi WebQual}

Dimensi Webqual 4.0 seperti yang telah dijelaskan diatas memiliki 3 dimensi yaitu kualitas informasi (information quality), kualitas interaksi (interaction quality) dan terakhir kemudahan penggunaan (usability)[4].

1. Kualitas informasi (information quality)

Kualitas informasi meliputi informasi yang akurat, informasi yang dapat dipercaya, informasi yang up to date, informasi sesuai dengan topik bahasan, kemudahan informasi untuk dimengerti, kedetailan informasi dan informasi yang disajikan dalam format desain yang sesuai.

2. Kualitas interaksi (interaction quality)

Kualitas interaksi meliputi kemampuan memberikan rasa aman saat transaksi, memliki reputasi yang bagus, memudahkan komunikasi, menciptakan perasaan emosional yang lebih personal, memiliki kepercayaan dalam memberikan informasi pribadi, mampu menciptakan komunitas yang spesifik, memberikan keyakinan bahwa janji yang disampaikan akan ditepati.

3. Kualitas kemudahan penggunaan (usability) Kualitas usability meliputi kemudahan website 


\begin{tabular}{|l|l|}
\hline No & Deskripsi Indikator \\
\hline 1 & Website memiliki reputasi yang baik \\
\hline 2 & $\begin{array}{l}\text { Pengguna merasa aman untuk } \\
\text { melakukan transaksi }\end{array}$ \\
\hline 3 & $\begin{array}{l}\text { Pengguna merasa aman terhadap } \\
\text { informasi pribadinya }\end{array}$ \\
\hline 4 & $\begin{array}{l}\text { Website memberi ruang untuk } \\
\text { personalisasi }\end{array}$ \\
\hline 5 & $\begin{array}{l}\text { Website memberikan ruang untuk } \\
\text { komunitas }\end{array}$ \\
\hline 6 & $\begin{array}{l}\text { Website memberikan kemudahan } \\
\text { untuk berkomunikasi dengan } \\
\text { organisasi }\end{array}$ \\
\hline 7 & $\begin{array}{l}\text { Pengguna merasa yakin bahwa } \\
\text { barang/jasa akan dikirim } \\
\text { sebagaimana yang telah dijanjikan }\end{array}$ \\
\hline
\end{tabular}

4. untuk dipelajari, kemudahan untuk dimengerti, kemudahan untuk ditelusuri, kemudahan untuk digunakan, kemenarikan website, interface yang

menyenangkan, memiliki kompetensi yang baik dan memberikan pengalaman baru yang menyenangkan.

Tabe1 1. Dimensi Kemudahan Penggunaan (usability)

\begin{tabular}{|l|l|}
\hline No & Deskripsi Indikator \\
\hline 1 & $\begin{array}{l}\text { Pengguna merasa mudah untuk } \\
\text { mempelajari pengoperasian website }\end{array}$ \\
\hline 2 & $\begin{array}{l}\text { Interaksi antara website dengan } \\
\text { pengguna jelas dan mudah dipahami }\end{array}$ \\
\hline 3 & $\begin{array}{l}\text { Pengguna merasa mudah untuk } \\
\text { bernavigasi dalam website }\end{array}$ \\
\hline 4 & $\begin{array}{l}\text { Pengguna merasa website mudah untuk } \\
\text { digunakan }\end{array}$ \\
\hline 5 & $\begin{array}{l}\text { Website memiliki tampilan yang } \\
\text { menarik }\end{array}$ \\
\hline 6 & Desain sesuai dengan jenis website \\
\hline 7 & Website mengandung kompetensi \\
\hline 8 & $\begin{array}{l}\text { Website menciptakan pengalaman } \\
\text { positif bagi pengguna }\end{array}$ \\
\hline
\end{tabular}

Sumber:

http://www.webqual.co.uk/instrument.htm

Tabe1 2. Dimensi Kualitas informasi (information quality)

\begin{tabular}{|l|l|}
\hline No & Deskripsi Indikator \\
\hline & $\begin{array}{l}\text { Website menyediakan informasi yang } \\
\text { urat }\end{array}$ \\
\hline 2 & $\begin{array}{l}\text { Website menyediakan informasi yang } \\
\text { terpercaya }\end{array}$ \\
\hline 3 & Website menyediakan informasi yang \\
\hline
\end{tabular}

\begin{tabular}{|l|l|}
\hline & tepat waktu \\
\hline 4 & $\begin{array}{l}\text { Website menyediakan informasi yang } \\
\text { relevan }\end{array}$ \\
\hline 5 & $\begin{array}{l}\text { Website menyediakan informasi yang } \\
\text { mudah dimengerti }\end{array}$ \\
\hline 6 & $\begin{array}{l}\text { Website memberikan informasi yang } \\
\text { detail pada level yang tepat }\end{array}$ \\
\hline 7 & $\begin{array}{l}\text { Website menyajikan informasi dalam } \\
\text { format yang tepat }\end{array}$ \\
\hline
\end{tabular}

Sumber: http://www.webqual.co.uk/instrument.htm

Tabe1 3. Dimensi Kualitas Interaksi (interaction quality)

Sumber: http://www.webqual.co.uk/instrument.htm

\section{METODE PENELITIAN}

Penelitian ini dilakukan melalui beberapa tahapan penelitian dengan menggunakan metode-metode tertentu. Adapun tahapan-tahapan penelitian yang dilakukan dapat dilihat pada gambar 1 berikut ini.

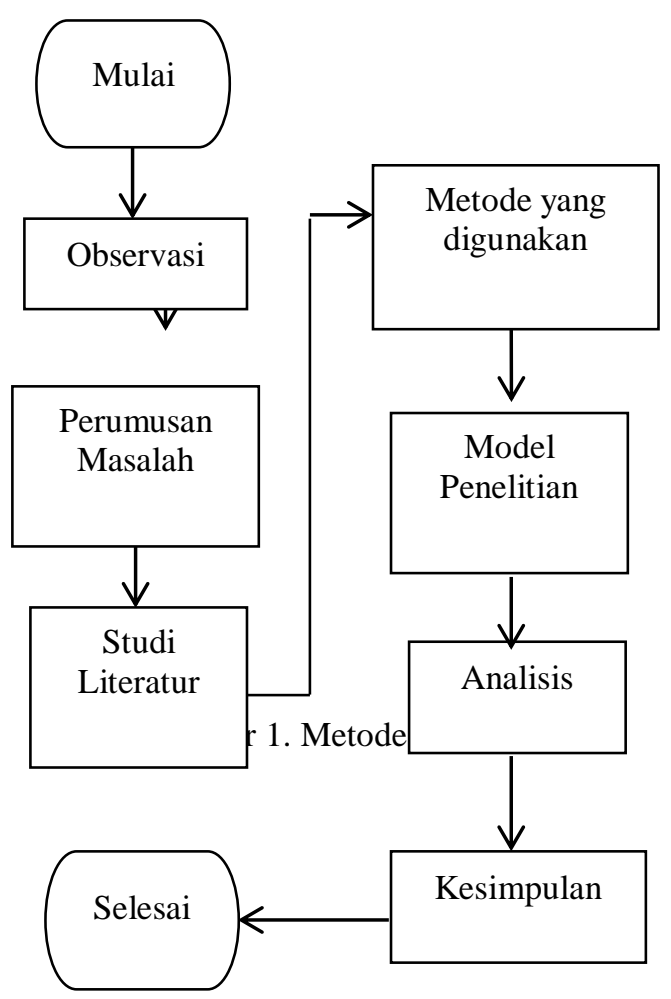

Pada gambar 1 diatas dapat dijelaskan sebagai berikut:

A. Kegiatan penelitian dimulai dengan melakukan pengamatan (observasi) terhadap kegiatan akademik yang dilakukan oleh mahasiswa di STMIK XYZ dan mengidentifikasi aplikasi atau sistem informasi yang terkait dengan kegiatan akademik tersebut. Dari hasil pengamatan diketahui ada satu aplikasi yang sifatnya kritikal 
dimana tanpa aplikasi tersebut maka kegiatan akademik akan terganggu. Kegiatan yang dimaksud adalah pengisian KRS dengan aplikasi yang digunakan adalah Sistem KRS Online berbasis web atau yang dikenal dengan nama Prisma Online yang menjadi objek penelitian dan mahasiswa sebagai subjek penelitiannya.

B. Setelah mendapatkan objek penelitian selanjutnya dilakukan perumusan masalah dengan cara mengidentifikasi masalahmasalah yang selama ini ditemui oleh mahasiswa sehubungan dengan pemanfaatan dari Prisma Online tersebut. Dari hasil identifikasi selanjutnya permasalahan tersebut dikelompokkan lagi menjadi satu pokok bahasan utama yaitu berkaitan dengan kualitas (quality) sistem informasi.

C. Berdasarkan masalah yang telah ditentukan langkah berikutnya adalah pencarian referensi ataupun tinjauan pustaka terhadap penelitian yang akan dilakukan serta dengan melakukan kajian terhadap literatur/penelitian yang pernah dilakukan sebelumnya oleh peneliti-peneliti lain. Dengan demikian dapat memperkaya hasil penelitian sebelumnya dan meningkatkan hasil penelitian yang sedang dilakukan.

D. Setelah melakukan studi literatur didapatkan beberapa metode dengan berbagai versi yang berhubungan dengan masalah kualitas. Dari beberapa metode tersebut ada yang telah digunakan pada penelitian sebelumnya untuk objek dan subjek penelitian yang sama. Melalui kajian secara mendalam dari berbagai metode yang ada ditetapkan untuk penelitian ini menggunakan metode WebQual 4.0. Metode ini dipilih karena sangat mewakili untuk pengukuran kualitas sistem informasi yang khusus berbasis web. Pengukuran dilakukan berdasarkan persepsi pengguna akhir. Ada 3 dimensi yang digunakan yaitu Dimensi Kemudahan Penggunaan (usability), Dimensi Kualitas informasi (information quality) dan Dimensi Kualitas Interaksi (interaction quality).

E. Untuk mendapatkan hasil penelitian dengan menggunakan metode WebQual terlebih dahulu dibuat suatu model penelitian yang menggambarkan bentuk hubungan antara variabel-variabel yang ada. Berdasarkan variabel-variabel tersebut selanjutnya dibuat suatu hipotesis yang pada akhirnya akan diuji untuk menentukan hasilnya. Adapun model penelitian yang dibuat dapat dilihat pada gambar 2 berikut ini:

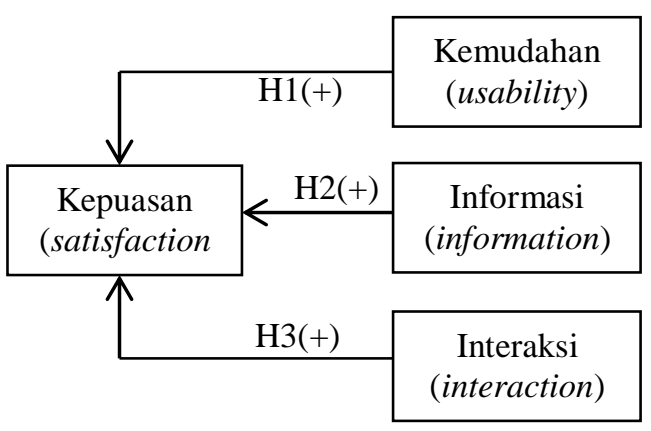

Gambar 2. Model Penelitian

Dari gambar 2 diperoleh model penelitian dengan menggunakan empat variabel yang terdiri dari 1 variabel terikat (dependent variable) dan 3 variabel bebas (independent variable). Variabel - variabel yang dimaksud adalah variabel kepuasan (satisfaction) yang merupakan variabel terikat lalu variabel kemudahan (usability), variabel informasi (information) serta variabel interaksi (interaction) yang merupakan variabel bebas. Dari keempat variabel tersebut dapat dibuat model penelitannya dalam bentuk persamaan regresi (1) sebagai berikut:

$\mathrm{S}=\mathrm{xU}+\mathrm{yI}+\mathrm{zT}$

Dari persamaan (1) dapat dijelaskan bahwa

S yang menyatakan User Satisfaction merupakan variabel mengenai kepuasan pengguna. Variabel ini digunakan untuk mengukur tingkat kepuasan mahasiswa terhadap pemanfaatan sistem Prisma Online.

U yang menyatakan Usability Quality merupakan variabel mengenai kualitas kemudahan penggunaan. Variabel ini digunakan untuk mengukur seberapa mudah suatu fitur/menu maupun fungsi-fungsi dari Prisma Online digunakan. Variabel ini berasosiasi dengan dimensi usability pada metode WebQual 4.0

I yang menyatakan Information Quality merupakan variabel mengenai kualitas informasi. Variabel ini digunakan untuk mengukur seberapa besar tingkat kualitas informasi (akurasi, kesesuaian, relevansi termasuk juga security) yang dihasilkan oleh sistem Prisma Online. Variabel ini berasosiasi dengan dimensi Information Quality pada metode WebQual 4.0 
T yang menyatakan Interaction Quality merupakan variabel mengenai kualitas interaksi. Variabel ini digunakan untuk mengukur seberapa besar tingkat interaksi pengguna terhadap sistem Prisma Online yang dapat dilihat bentuknya dari kepercayaan pengguna dalam pemakaiannya untuk kegiatan akademik. Variabel ini berasosiasi dengan dimensi Interaction Quality pada metode WebQual 4.0. Pada persamaan regresi (1) $\mathrm{x}, \mathrm{y}$ dan $\mathrm{z}$ merupakan koefisien untuk tiap-tiap variabel bebas yang nilainya akan dihitung kemudian melaui uji t.

F. Setelah model penelitian terbentuk tahapan selanjutnya adalah melakukan analisis. Namun sebelum tahap analisis ini dilakukan tentu harus memiliki data-data yang dikumpulkan terlebih dahulu menggunakan metode tertentu yang akhirnya akan diolah menggunakan alat bantu perangkat lunak statistik. Dalam penelitian ini digunakan perangkat lunak SPSS (Statistical Package for the Social Sciences). Metode pengumpulan data yang digunakan dalam penelitian ini adalah kuesioner. Kuesioner dilakukan kepada mahasiswa STMIK XYZ sebagai sampel dari beberapa program studi yaitu Sistem Informasi, Teknik Informatika dan Manajemen Informatika. Adapun untuk penentuan ukuran sampel mahasiswa yang terlibat dalam pengisian kuesioner dilakukan dengan menggunakan rumus Slovin (2) yaitu

$\mathrm{n}=\mathrm{N} /\left(1+\mathrm{N}(\mathrm{e})^{2}\right)$

dimana:

$\mathrm{n} \quad=$ jumlah sampel

$\mathrm{N} \quad=$ jumlah populasi

e $\quad=$ standar kesalahan (error) sebesar $10 \%$

Diketahui populasi mahasiswa STMIK XYZ berjumlah 684 mahasiswa. Dengan menggunakan rumus Slovin (2) maka jumlah sampel untuk penelitian ini diperoleh sebesar

$\mathrm{n}=684 /\left(1+684(0,1)^{2}\right)=87,2$

Berdasarkan hasil perhitungan diatas (3) jumlah sampel yang digunakan sebanyak 87 mahasiswa. Kuesioner yang dibuat menggunakan pertanyaan tertutup dan skala pengukuran yang digunakan adalah skala Likert seperti yang ditunjukan pada tabel 4 berikut ini:

Tabe1 4. Skala Likert

\begin{tabular}{|l|l|}
\hline Skala & Keterangan \\
\hline 1 & sangat tidak setuju \\
\hline
\end{tabular}

\begin{tabular}{|l|l|}
\hline 2 & tidak setuju \\
\hline 3 & netral \\
\hline 4 & setuju \\
\hline 5 & sangat setuju \\
\hline
\end{tabular}

Butir-butir pertanyaan yang dibuat dalam kuesioner harus dipastikan terlebih dahulu kelayakannya karena suatu variabel yang akan digunakan dalam penelitian harus memiliki sifat valid dan dapat diandalkan (reliable). Untuk menguji apakah butir-butir pertanyaan yang diajukan dalam kuesioner sudah valid dan reliabel atau tidak dilakukan dengan melakukan uji validitas dan realibilitas. Apabila tidak valid maka butir pertanyaan tersebut akan dibuang dari model penelitian. Selanjutnya analisis korelasi digunakan untuk melihat hubungan atau koefisien korelasi antara ketiga independent variable dan dependent variable apakah memiliki korelasi yang positif atau tidak? Metode analisis yang digunakan untuk menganalisis data yang didapat dari sampel adalah dengan menggunakan metode perhitungan statistik, yaitu metode regresi linier berganda, yang terdiri atas uji korelasi regresi secara simultan (Uji F) dan uji koefisien regresi secara individu/parsial (Uji t).

G. Setelah semua kegiatan analisis dilakukan pada tahap selanjutnya dilakukan penarikan kesimpulan

\section{HASIL DAN PEMBAHASAN}

Pengisian KRS online dilakukan mahasiswa pada setiap awal semester gasal dan genap. Pengisian dilakukan dengan sesuai hasil konsultasi dengan dosen pembimbing dan berdasarkan mata kuliah yang ditawarkan pada semester tersebut.

\subsection{Penyebaran Kuesioner}

Untuk pengumpulan data pada penelitian ini dilakukan dengan menggunakan metode kuesioner. Penyebaran kuesioner dilakukan dengan memanfaatkan aplikasi Google Form yang dapat diakses secara online. Banyak kemudahan yang didapatkan melalui aplikasi tersebut diantaranya adalah kemudahan dalam proses pengumpulan data karena pengisian kuesioner dapat dilakukan kapan saja dan dimana saja. Ada 22 pertanyaan yang diajukan kepada responden. Semua pertanyaan yang dibuat dalam bentuk pertanyaan yang tertutup dimana responden telah disediakan pilihan jawaban yang jumlahnya menyesuaikan skala Likert yang sudah ditetapkan. Responden hanya diberikan alamat web yang harus diakses dalam periode waktu tertentu untuk melakukan pengisian. Semua responden yang berjumlah 87 telah mensubmit jawaban dengan status semua pertanyaan terisi semua. Distribusi responden 
berdasarkan program studi dapat dilihat pada tabel 5 berikut ini:

Tabe1 5. Jumlah Responden berdasarkan Prodi

\begin{tabular}{|l|l|}
\hline Prodi & Jumlah \\
\hline Sistem Informasi & 62 \\
\hline Teknik Informatika & 18 \\
\hline Managemen Informatika & 7 \\
\hline Total & 87 \\
\hline
\end{tabular}

Dari tabel 5 dapat dilihat bahwa responden terbanyak berasal dari jurusan Sistem Informasi. Hal ini sesuai dengan fakta dilapangan bahwa di STMIK XYZ mahasiswa yang terbanyak memang dari program studi Sistem Informasi diikuti oleh Teknik Informatika dan Managemen Informatika.

\subsection{Uji Validitas dan Reliabilitas}

Uji validitas dilakukan untuk mengetahui apakah suatu instrumen alat ukur telah menjalankan fungsi ukurnya. Menurut [5], validitas menunjukkan ketepatan dan kecermatan alat ukur dalam melakukan fungsi ukurnya. Suatu skala pengukuran disebut valid bila ia melakukan apa yang seharusnya dilakukan dan mengukur apa yang harus diukur [6]. Dalam penelitian ini Uji validitas dilakukan dengan menggunakan metode analisis faktor, sedangkan uji reliabilitas dilakukan dengan menggunakan Cronbach Alpha. Prose pengujian dilakukan dengan alat bantu software statistik SPSS. Hasil uji validitas dapat dilihat pada tabel 6 berikut ini:

\section{Tabe1 6. Uji Validitas}

Dari tabel 6 dapat dilihat nilai Corrected ItemTotal Correlation dari masing-masing 22 butir pertanyaan untuk independent variable. Nilai yang muncul berkisar antara 0,124 - 0,762. Nilai terendah untuk variabel I3 yaitu berkaitan dengan apakah Prisma Online menyediakan informasi yang tepat waktu. Nilai tertinggi untuk variabel T2 yaitu berkaitan dengan apakah Pengguna merasa aman untuk melakukan transaksi. Sedangkan $r$ table (tabel koefisien relasi dengan metode product momen) dengan signifikansi $5 \%$ dan jumlah sampling $(n=87)$ diperoleh $r$ tabel dengan nilai 0,303. Diketahui syarat indikator suatu variabel yang dinyatakan dengan setiap item pernyataan kuesioner tersebut valid adalah jika nilai setiap item pertanyaan kuesioner mempunyai nilai
Corrected Item-Total Correlation lebih besar dari $r$ table. Jika dibandingkan dengan nilai $r$ table, semua indikator valid, kecuali indikator I3 tidak valid $(<0,303)$, maka dikeluarkan

\begin{tabular}{|c|c|c|c|c|}
\hline 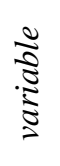 & $\begin{array}{l}\text { Scale } \\
\text { Mean if } \\
\text { Item } \\
\text { Deleted }\end{array}$ & $\begin{array}{l}\text { Scale } \\
\text { Variance } \\
\text { if Item } \\
\text { Deleted }\end{array}$ & $\begin{array}{l}\text { Corrected } \\
\text { Item-Total } \\
\text { Correlatio } \\
n\end{array}$ & $\begin{array}{l}\text { Cronbach's } \\
\text { Alpha if Item } \\
\text { Deleted }\end{array}$ \\
\hline U1 & 64,03 & 33,395 & 0,541 & 0,903 \\
\hline $\mathrm{U} 2$ & 64,21 & 32,885 & 0,411 & 0,901 \\
\hline U3 & 64,16 & 31,623 & 0,494 & 0,902 \\
\hline U4 & 64,02 & 33,371 & 0,568 & 0,901 \\
\hline U5 & 64,63 & 32,180 & 0,460 & 0,903 \\
\hline U6 & 64,23 & 32,339 & 0,559 & 0,897 \\
\hline U7 & 64,28 & 33,270 & 0,618 & 0,902 \\
\hline U8 & 64,17 & 34,197 & 0,479 & 0,901 \\
\hline I1 & 64,21 & 34,550 & 0,372 & 0,903 \\
\hline I2 & 64,07 & 33,781 & 0,540 & 0,902 \\
\hline I3 & 64,15 & 34,906 & 0,124 & 0,910 \\
\hline I4 & 64,14 & 33,568 & 0,606 & 0,901 \\
\hline I5 & 64,22 & 34,010 & 0,540 & 0,902 \\
\hline I6 & 64,26 & 33,719 & 0,543 & 0,902 \\
\hline I7 & 64,16 & 32,901 & 0,754 & 0,895 \\
\hline $\mathrm{T} 1$ & 64,23 & 33,550 & 0,593 & 0,901 \\
\hline $\mathrm{T} 2$ & 64,19 & 33,060 & 0,762 & 0,887 \\
\hline $\mathrm{T} 3$ & 64,33 & 32,225 & 0,641 & 0,879 \\
\hline $\mathrm{T} 4$ & 64,47 & 33,110 & 0,459 & 0,904 \\
\hline T5 & 64,37 & 32,921 & 0,421 & 0,903 \\
\hline T6 & 64,49 & 33,350 & 0,451 & 0,905 \\
\hline $\mathrm{T} 7$ & 64,28 & 33,346 & 0,598 & 0,897 \\
\hline
\end{tabular}
selanjtnya adalah dilakukan uji reliabilitas. Uji reliabilitas dilakukan untuk mengetahui konsistensi alat ukur, dapat diandalkan dan tetap konsisten jika pengukuran tersebut dilakukan secara berulang atau tidak. Selain itu, perhitungan reliabilitas juga dilakukan untuk mengetahui hasil dari jawaban yang diberikan oleh responden dapat digunakan untuk tahap pengolahan berikutnya atau tidak. Dalam penelitian ini uji reliabilitas dilakukan dengan menggunakan Cronbach Alpha. Hasil pengujian dapat dilihat pada tabel 7 berikut ini:

Tabe1 7. Uji Reliabilitas

Reliability Statistics 


\begin{tabular}{|c|c|c|}
\hline $\begin{array}{l}\text { Cronbach's } \\
\text { Alpha }\end{array}$ & $\begin{array}{l}\text { lronbach's Alpha } \\
\text { Based on } \\
\text { Standardized } \\
\text { Items }\end{array}$ & N of Items \\
\hline 0.906 & 0.912 & 22 \\
\hline
\end{tabular}

Berdasarkan hasil uji reliabilitas pada tabel 7 diperoleh nilai Cronbach's Alpha 0,906. Dengan demikian berarti nilai alpha $>0,9$ yang berarti reliabilitas model sangat baik[7].

3.3 Analisis Pengaruh Usability Quality, Information Quality, dan Interaction Quality terhadap User Satisfaction

\subsubsection{Analisis Korelasi}

Pada tabel 8 dapat dilihat hubungan atau koefisien korelasi antara ketiga independent variable dan dependent variable signifikan.

Tabe1 8. Koefisien Korelasi

\section{Correlations}

\begin{tabular}{|c|c|c|c|c|}
\hline & 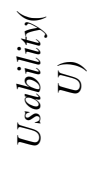 & 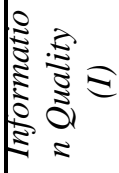 & 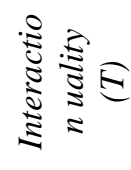 & 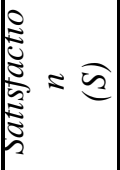 \\
\hline $\begin{array}{cc}\text { Usabi } & \text { Pear } \\
\text { lity } & \text { son } \\
\text { (U) } & \text { Corr } \\
& \text { elati } \\
& \text { on } \\
& \text { Sig, } \\
& (2- \\
\text { taile } & \\
\text { d) } & \end{array}$ & 87 & $\begin{array}{r}0,535^{* *} \\
0,000\end{array}$ & $0,555^{* *}$ & $0,800^{* *}$ \\
\hline $\begin{array}{cc}\text { Infor } & \text { Pear } \\
\text { matio } & \text { son } \\
n & \text { Corr } \\
n & \text { Quali } \\
\text { ty } & \text { on } \\
\text { (I) } & \text { Sig, } \\
& (2- \\
& \text { taile } \\
& d) \\
& N\end{array}$ & $\begin{array}{l}, 535^{* *} \\
, 000\end{array}$ & 87 & $0,570^{* *}$ & $0,800^{* *}$ \\
\hline
\end{tabular}

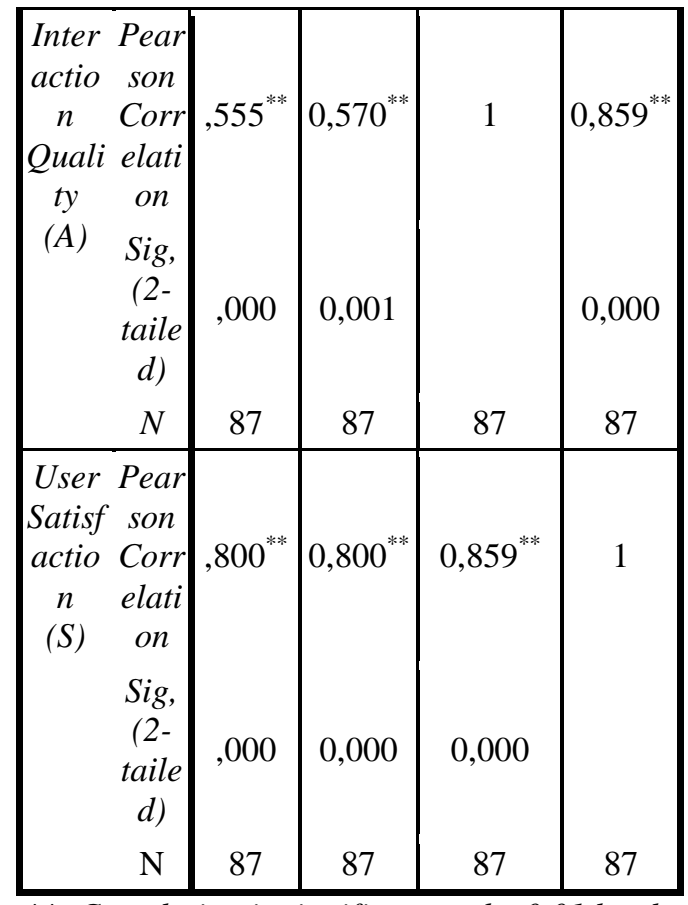

**, Correlation is significant at the 0,01 level (2-tailed)

Berdasarkan tabel 8 diatas diketahui nilai-nilai koefisien korelasi untuk variabel $\mathrm{U}$ (Usability), I (Information Quality) dan T (Interaction Quality). Adapun nilai-nilai koefisien korelasi untuk variabel U (Usability), I (Information Quality) dan T (Interaction Quality) terhadap S (User Satisfaction) adalah bertutur-turut sebesar 0,8; 0,$8 ;$ dan 0,859. Berdasarkan ketentuan keeratan korelasi antar variabel [7] koefisien korelasi (kk) yang ditunjukkan di tabel 8 menun

menunjukkan adanya korelasi positif yang cukup berarti untuk variabel $\mathrm{U}$ dan I terhadap $\mathrm{S}$ dengan nilai koefisien korelasi $(0,5<\mathrm{kk} \leq 0,8)$. Sedangkan untuk variabel $\mathrm{T}$ dan $\mathrm{S}$ menunjukkan adanya korelasi positif yang tinggi atau kuat dengan nilai koefisien korelasi $(0,6<\mathrm{kk} \leq 0,8)$.

\subsubsection{Analisis Regresi}

Pengujian hipotesis bagi koefisien regresi berganda atau regresi parsial parameter B1 dan B2 dapat dibedakan menjadi dua bentuk, yaitu pengujian hipotesis serentak dan pengujian hipotesis individual [7]. Pengujian hipotesis serentak merupakan pengujian hipotesis koefisien regresi berganda dengan B1 dan B2 serentak atau bersama-sama mempengaruhi $\mathrm{Y}$, formulasi hipotesisnya yaitu sebagai berikut: 
$\mathrm{H} 0: \mathrm{B} 1=\mathrm{B} 2=0 \quad(\mathrm{X} 1, \quad \mathrm{X} 2, \quad$ dan $\quad \mathrm{X} 3$ tidak mempengaruhi $\mathrm{Y})$

$\mathrm{H} 1: \mathrm{B} 1 \neq \mathrm{B} 2=0(\mathrm{X} 1, \mathrm{X} 2$, dan $\mathrm{X} 3$ mempengaruhi $\mathrm{Y}$ atau paling sedikit ada $\mathrm{X}$ yang mempengaruhi Y)

dalam hal ini X1 adalah variabel Usability Quality, X2 adalah variabel Information Quality, dan X3 adalah variabel Interaction Quality. Ketiga variable $\mathrm{X}$ tersebut sebagai independent variable. Sedangkan variabel dependent adalah variable Y yaitu User Satisfaction. Dengan menggunakan uji $\mathrm{F}$, diperoleh hasil pengujian hipotesis untuk pengujian serentak dalam tabel 9 (tabel ANOVA) berikut ini:

Tabe1 9. Hasil Uji F

\begin{tabular}{|c|c|c|c|c|c|}
\hline \multicolumn{6}{|c|}{$A N O V A^{b}$} \\
\hline Model & $\begin{array}{l}\text { Sum of } \\
\text { Squares }\end{array}$ & $d f$ & $\begin{array}{l}\text { Mean } \\
\text { Square }\end{array}$ & $F$ & Sig. \\
\hline $\begin{array}{l}1 \text { Regressi } \\
\text { on }\end{array}$ & 40,101 & 3 & 12,367 & $\begin{array}{c}42,36 \\
7\end{array}$ & $0,000^{\mathrm{a}}$ \\
\hline Residual & 11,576 & 37 & 0,315 & & \\
\hline Total & 51,678 & 42 & & & \\
\hline
\end{tabular}

a. Predictors: (Constant), Interaction_Quality, Information_Quality, Usability

b. Dependent Variable: Uer_Satisfaction

Berdasarkan hasil uji $\mathrm{F}$ di atas, diperoleh nilai signifikansi(sig.) adalah $0,000<0,05(\alpha)$, artinya H0 ditolak dan H1 diterima. Hal ini menyatakan bahwa variabel Usability Quality, Information Quality, dan Interaction Quality secara serentak atau bersama-sama mempengaruhi variabel User Satisfaction. Untuk pengujian hipotesis individual dilakukan dengan menggunakan uji t, formulasi hipotesisnya yaitu sebagai berikut: $\mathrm{H} 0: \mathrm{Bi}=0$ (tidak ada pengaruh Xi terhadap $\mathrm{Y}$ ) $\mathrm{H} 1: \mathrm{Bi} \neq 0$ (ada pengaruh $\mathrm{Xi}$ terhadap $\mathrm{Y}$ ) Hasil pengujian hipotesis koefisien regresi berganda untuk pengujian individual dalam dilihat pada tabel 10 berikut ini:

Tabe1 10. Hasil Uji t

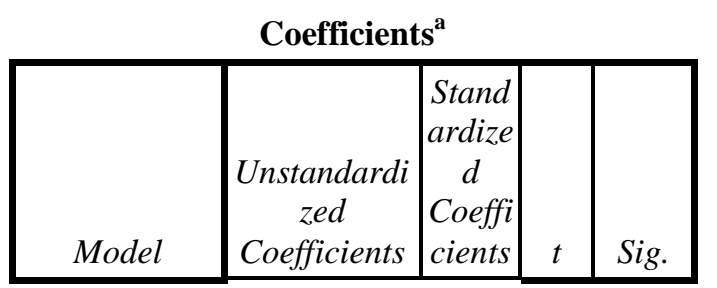

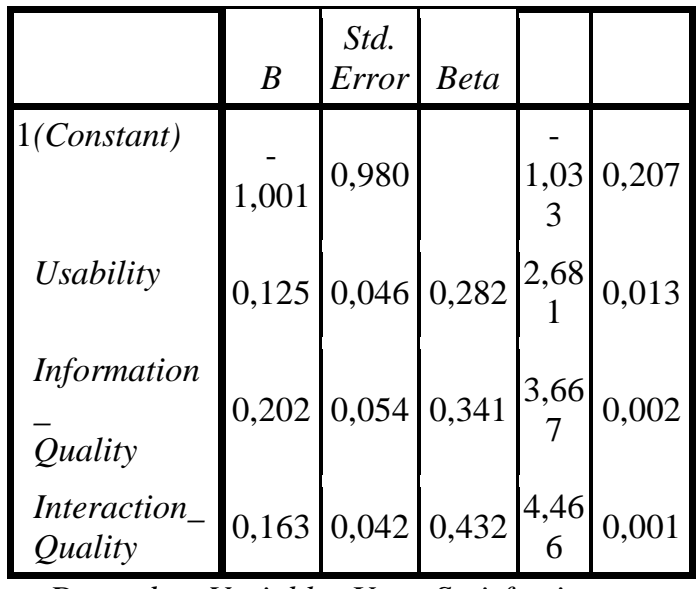

a. Dependent Variable: User_Satisfaction

Berdasarkan hasil uji $\mathrm{t}$ di atas, diperoleh nilai signifikansi(sig.) untuk variabel Usability Quality, Information Quality, dan Service Interaction < 0,05 $(\alpha)$, artinya $\mathrm{H} 0$ ditolak dan $\mathrm{H} 1$ diterima. dengan demikian semua variabel bebas (independent variable) yaitu Usability Quality, Information Quality, dan Service Interaction berpengaruh terhadap variabel User Satisfaction. Sedangkan untuk nilai konstanta regresi tidak berpengaruh karena nilai sig. > 0,05, sehingga akan dikeluarkan dari persamaan regresinya. Jadi, dari hasil analisis regresi tersebut dapat disimpulkan persamaan regresi pengaruh Usability Quality, Information Quality, dan Service Interaction terhadap User Satisfaction adalah

$S=0,125 U+0,202 I+0,163 T$

\section{KESIMPULAN}

Berdasarkan dari hasil analisis dengan menggunakan data yang ada dapat disimpulkan bahwa semua dimensi pengukuran kualitas sangat mempengaruhi kepuasan penggunaan Sistem KRS Online (Prisma Online). Dengan demikian STMIK XYZ harus dapat lebih meningkatkan kualitas layanan dari sistem tersebut. Peningkatan fitur-fitur yang berhubungan dengan dimensi kualitas harus terus dilakukan. Untuk layanan yang sudah baik pihak manajemen harus dapat mempertahankannya.

\section{DAFTAR PUSTAKA}

[1] Amelia, Lisa. "Analisis Usability Aplikasi Pengisian KRS Online STMIK XYZ Palembang Menggunakan USE Questionaire". Jurnal Informasi Dan Komputer 7.1 (2019): 17-27

[2] International Organization for Standardization. ISO 9241-11: Guidance on Usability. 1998. 
[3] Tarigan. "User Satisfaction Using WebQual Instrument: A Research on Stock Exchange of Thailand (SET)", Jurnal Akuntansi dan Keuangan, X.I (2008):34-37

[4] Iman Sanjaya,"Pengukuran Kualitas Layanan Website KEMENTERIAN KOMINFO Dengan Menggunakan Metode Webqual 4.0", Jurnal Penelitian IPTEK-KOM, XIV.I (2012):1-114

[5] Sekaran, Uma. Research Methods for business: Skill-Building Approach. fourth edition. New York: John Wiley \& Sons Inc. 2003.

[6] Wijaya, Tony. Cepat Menguasai SPSS 19 untuk Olah dan Interpretasi, Cahaya Atma,Kelompok Penerbit Univ. Atmajaya Yogyakarta. Cetakan ke-5.2015.

[7] Hasan, M. Iqbal, Pokok-Pokok Materi Statistik 2 (Statistik Inferensi), Bumi Aksara, (2005), pp: 
